\title{
Cadmium and zinc uptake and translocation in dwarf Polish wheat seedlings as affected by calcium and potassium combination
}

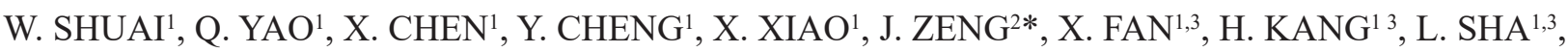 \\ H. ZHANG ${ }^{1,3}$, Y. ZHOU ${ }^{1,3}$, and Y. WANG ${ }^{1,3 *}$ \\ Triticeae Research Institute, Sichuan Agricultural University, Wenjiang 611130, Sichuan, P.R. China \\ College of Resources, Sichuan Agricultural University, Wenjiang 611130, Sichuan, P.R. China ${ }^{2}$ \\ Joint International Research Laboratory of Crop Resources and Genetic Improvement, \\ Sichuan Agricultural University, Wenjiang 611130, Sichuan, P.R. China ${ }^{3}$
}

\begin{abstract}
Combination of calcium and potassium $(\mathrm{Ca}-\mathrm{K})$ influences cadmium and zinc uptake and translocation in dwarf Polish wheat (Triticum polonicum), but its effects remain unclear. In the present study, a high concentration of Ca-K reduced uptake of $\mathrm{Cd}$ and $\mathrm{Zn}$ by roots and promoted their translocations to shoots under $\mathrm{Cd}$ and $\mathrm{Zn}$ excess. Whatever under a low or high concentration of $\mathrm{Ca}-\mathrm{K}, \mathrm{Zn}$ inhibited $\mathrm{Cd}$ uptake and translocation under $\mathrm{Cd}+\mathrm{Zn}$ stress when compared with $\mathrm{Cd}$ stress alone. However, the reduced $\mathrm{Cd}$ content caused by $\mathrm{Zn}$ under the high concentration of Ca-K was significantly lower than under the low concentration of $\mathrm{Ca}-\mathrm{K}$. Under both $\mathrm{Ca}-\mathrm{K}$ treatments, $\mathrm{Cd}$ promoted $\mathrm{Zn}$ uptake and inhibited $\mathrm{Zn}$ translocation under $\mathrm{Cd}+\mathrm{Zn}$ stress when compared with those under $\mathrm{Zn}$ stress. The high concentration of $\mathrm{Ca}-\mathrm{K}$ reinforced the promotion of $\mathrm{Zn}$ uptake and the inhibition of $\mathrm{Zn}$ translocation caused by $\mathrm{Cd}$. The $\mathrm{Ca}-\mathrm{K}$ or $\mathrm{Zn}$ affected the expression of several metal transporters and influenced cell wall metabolism, the subcellular distribution of $\mathrm{Cd}$, and the Cd chemical forms. Meanwhile, $\mathrm{Ca}-\mathrm{K}$ or $\mathrm{Cd}$ also affected the expressions of several metal transporters and changed the subcellular distribution of $\mathrm{Zn}$. The differentially expressed metal transporters and changes in subcellular distributions and Cd chemical forms were associated with $\mathrm{Cd}$ and $\mathrm{Zn}$ uptake and translocation. In summary, the application of Ca-K caused changes in gene expression, $\mathrm{Cd}$ and $\mathrm{Zn}$ uptake, translocation, and subcellular distribution.
\end{abstract}

Additional key words: Cd chemical forms, $\mathrm{Cd} / \mathrm{Zn}$ interaction, gene expression, metal transporters, subcellular distribution, Triticum polonicum.

\section{Introduction}

Cadmium is one of the most toxic heavy metals for all living organisms, even at low concentrations. An increasing proportion of arable soils worldwide have been contaminated with $\mathrm{Cd}$ released as a result of human activities or environmental causes (Perrier et al. 2016, $\mathrm{Li}$ et al. 2017). Given that $\mathrm{Cd}$ is a non-essential element, no specific transporter is responsible for $\mathrm{Cd}$ uptake and translocation by plants (Sasaki et al. 2012). Plants absorb and distribute Cd via the pathway(s) responsible for the uptake and transport of essential ions, such as calcium, iron, and zinc (Clemens 2006, Sasaki et al. 2012, Sharma et al. 2016, Wang et al. 2017a). Thus, Zn and Fe may affect Cd uptake or accumulation (Hart et al. 2002, 2005, Sun et al. 2005, Balen et al. 2011, Cheng et al. 2018), although the effects depend on the exogenous bioavailable $\mathrm{Cd} / \mathrm{Zn}$ concentrations, species, tissues, developmental stages, and nutritional conditions.

In wheat, application of $\mathrm{Zn}$ fertilizer has been used as an agronomic practice to reduce $\mathrm{Cd}$ uptake and accumulation. Hart et al. (2002, 2005) and Sun et al. (2005) reported that $\mathrm{Cd}$ and $\mathrm{Zn}$ mutually inhibited their uptake and translocation in roots and shoots in some genotypes of durum and bread wheat. However, mutual promotion of $\mathrm{Cd}$ and $\mathrm{Zn}$ uptake has been observed in bread wheat (Nan et al. 2002). Thus, $\mathrm{Zn}$ inhibition or promotion of Cd uptake differs among wheat species and genotypes. In dwarf Polish wheat (DPW; Triticum polonicum L., AABB, $2 n=$ $4 x=28$ ), we previously observed mutual inhibition of $\mathrm{Cd}$ and $\mathrm{Zn}$ uptake by each other and that $\mathrm{Cd}$ translocation was influenced by $\mathrm{Zn}$. In addition, a number of genes involved

Submitted 20 June 2019, last revision 2 December 2019, accepted 19 December 2019.

Abbreviations: ABC transporter - ATP-binding cassette transporter; CK - control; DPW - dwarf Polish wheat; HAc - acetic acid; HMA - heavy metal P-type ATPase; NAS - nicotianamine synthase; $\mathrm{NH}_{4}{ }^{+}-\mathrm{N}$ - ammonium nitrogen; $\mathrm{NO}_{3}{ }^{-}-\mathrm{N}$ - nitrate nitrogen; $\mathrm{NRT}^{-}$- nitrate transporter 1; RNA-Seq - RNA sequencing; TF - translocation factor; VIT - vacuolar iron transporter; YSL - yellow stripe-like protein. Acknowledgements: The authors thank the National Natural Science Foundation of China (No. 31671688). We thank Dr. Robert McKenzie from Liwen Bianji, Edanz Group China (www.liwenbianji.cn/ac), for editing the English text of a draft of this manuscript.

* Corresponding authors; e-mails: zengjian@sicau.edu.cn, wangyi@sicau.edu.cn 
in $\mathrm{Ca}$ and $\mathrm{K}$ ion channels were differentially regulated by $\mathrm{Cd}, \mathrm{Zn}$, and $\mathrm{Cd}+\mathrm{Zn}$ stresses (Wang et al. 2016, 2017b). Thus, $\mathrm{Ca}$ and $\mathrm{K}$ may participate in the $\mathrm{Cd} / \mathrm{Zn}$ interactions.

As essential elements, $\mathrm{Ca}$ and $\mathrm{K}$ are required for nitrogen $(\mathrm{N})$ metabolism, play diverse roles in cell wall and membrane structure, and cellular signal transduction (Siddiqui et al. 2012, Ahmad et al. 2016). Thus, the two elements play important roles in plant growth and development. In addition, $\mathrm{Ca}$ and $\mathrm{K}$ may reduce $\mathrm{Cd}$ and/ or $\mathrm{Zn}$ uptake in plants (such as tobacco, soybean, wheat, chickpea, and faba bean), thereby alleviating $\mathrm{Cd}$ toxicity and enhancing tolerance of $\mathrm{Cd}$ and $\mathrm{Zn}$ (Siddiqui et al. 2012, Song et al. 2015, Yang and Juang 2015, Ahmad et al. 2016, Wang et al. 2017a). Interestingly, combined application of $\mathrm{Ca}$ and $\mathrm{K}$ (hereafter $\mathrm{Ca}-\mathrm{K}$ ) is more effective in reducing $\mathrm{Cd}$ uptake and alleviating $\mathrm{Cd}$ toxicity compared with the individual effects of $\mathrm{Ca}$ and $\mathrm{K}$ applications (Siddiqui et al. 2012, Ahmad et al. 2016). Thus, Ca-K is a desirable strategy to inhibit $\mathrm{Cd}$ entry into the food chain. These studies have mainly focused on $\mathrm{Ca}-\mathrm{K}$ alleviation of $\mathrm{Cd}$ toxicity through investigating several physiological and biochemical indexes (Siddiqui et al. 2012, Ahmad et al. 2016).

Polish wheat shows low genetic similarity with T. durum, T. turgidum, and T. aestivum (Wiwart et al. 2013). A Chinese accession of DPW has been reported to show high tolerance to $\mathrm{Cd}$ and $\mathrm{Zn}$ (Wang et al. 2017b). In DPW seedlings, ammonium nitrogen $\left(\mathrm{NH}_{4}{ }^{+}-\mathrm{N}\right)$ reinforced the inhibition of $\mathrm{Cd}$ uptake and the promotion of $\mathrm{Cd}$ translocation caused by $\mathrm{Zn}$, but alleviated the inhibition of $\mathrm{Zn}$ uptake and partially reduced the promotion of $\mathrm{Zn}$ translocation stimulated by $\mathrm{Cd}$ (Cheng et al. 2018). Additionally, previous study indicated that the Fe accumulation could alleviate Cd toxicity (Wu et al. 2012), because it functions in various important processes, including photosynthesis, respiration, and chlorophyll biosynthesis (Kobayashi and Nishizawa 2012). However, the effects of $\mathrm{Ca}-\mathrm{K}$ on $\mathrm{Cd}$ and $\mathrm{Zn}$ uptake and translocation, and $\mathrm{Cd} / \mathrm{Zn}$ interactions were not investigated. In the present study, we hypothesized that a high concentration of $\mathrm{Ca}-\mathrm{K}$, compared with a low concentration of $\mathrm{Ca}-\mathrm{K}$, would reduce $\mathrm{Cd}, \mathrm{Zn}$, and $\mathrm{Fe}$ uptake, promote $\mathrm{Cd}$ and $\mathrm{Zn}$ translocation, and change the $\mathrm{Cd} / \mathrm{Zn}$ interaction. To test this hypothesis, we analyzed the $\mathrm{Cd}, \mathrm{Zn}$ and $\mathrm{Fe}$ content in roots and shoots, the translocation factor and subcellular distribution for both elements, the $\mathrm{Cd}$ chemical forms, and gene expression profiles under $\mathrm{Cd}, \mathrm{Zn}$, and $\mathrm{Cd}+\mathrm{Zn}$ stresses concomitant with a low or high concentration of $\mathrm{Ca}-\mathrm{K}$.

\section{Materials and methods}

Plants and growth conditions: Dwarf Polish wheat (Triticum polonicum L.) was collected from Xinjiang, China and the plants were cultivated as described by Cheng et al. (2018) with some modification of treatments. Briefly, after germination, uniform seedlings were grown in hydroponic culture with nutrient solution [ $4 \mathrm{mM} \mathrm{Ca}\left(\mathrm{NO}_{3}\right)_{2} \cdot 4 \mathrm{H}_{2} \mathrm{O}$, $5 \mathrm{mM} \mathrm{KNO}_{3}, 1 \mathrm{mMNH}_{4} \mathrm{NO}_{3}, 1 \mathrm{mM} \mathrm{KH}_{2} \mathrm{PO}_{4}, 2 \mathrm{mM} \mathrm{MgSO}_{4}$ - $7 \mathrm{H}_{2} \mathrm{O}, 10 \mu \mathrm{M} \mathrm{H}_{3} \mathrm{BO}_{3}, 1.8 \mu \mathrm{M} \mathrm{MnSO}_{4}, 0.2 \mu \mathrm{M} \mathrm{NaMoO}_{4}$,
$0.31 \mu \mathrm{M} \mathrm{CuSO}_{4}, 5 \mu \mathrm{M} \mathrm{ZnSO}_{4}$, and $50 \mu \mathrm{M}$ Fe-EDDHA, $\mathrm{pH} 6.0]$ in a growth chamber at a temperature $25{ }^{\circ} \mathrm{C}$, a 16-h photoperiod, an irradiance of $180 \mu \mathrm{mol} \mathrm{m} \mathrm{m}^{-2} \mathrm{~s}^{-1}$, and a relative humidity of $75 \%$. After two weeks, all seedlings were divided into two groups (with low and high concentrations of $\mathrm{Ca}-\mathrm{K}$ ) each with four subgroups, which were individually treated with $0 \mu \mathrm{M} \mathrm{CdCl}_{2}(\mathrm{CK})$, $80 \mu \mathrm{M} \mathrm{CdCl}_{2}(\mathrm{Cd}), 500 \mu \mathrm{M} \mathrm{ZnSO}_{4}(\mathrm{Zn})$, or $80 \mu \mathrm{M} \mathrm{CdCl}_{2}$ $+500 \mu \mathrm{M} \mathrm{ZnSO}_{4}(\mathrm{Cd}+\mathrm{Zn})$. For the high concentration of $\mathrm{Ca}-\mathrm{K}$ group, each treatment was supplemented with $5 \mathrm{mM}$ $\mathrm{KNO}_{3}$ and $4 \mathrm{mM} \mathrm{Ca}\left(\mathrm{NO}_{3}\right)_{2} \cdot 4 \mathrm{H}_{2} \mathrm{O}$. In addition, $1 \mathrm{mM}$ $\mathrm{Ca}\left({ }^{15} \mathrm{NO}_{3}\right)_{2}$ was incorporated in the nutrient solution to track the capacity of DPW for instantaneous absorption of $\mathrm{NO}_{3}^{-}$. Each treatment was conducted with three independent biological replicates (60 plants per biological replicate). On the seventh day of treatment, seedlings were sampled to measure root and shoot lengths, then were dried to analyze metal $(\mathrm{Cd}, \mathrm{Fe}$, and $\mathrm{Zn})$ content. The remaining plants were used to analyze the subcellular distribution of $\mathrm{Cd}$ and $\mathrm{Zn}, \mathrm{Cd}$ chemical forms, and gene expression.

Measurement of $\mathrm{Cd}, \mathrm{Zn}$, and Fe content and translocation: As described by Cheng et al. (2018), dried powder $(0.2 \mathrm{~g})$ of the root and shoot of each sample was digested with $\mathrm{HNO}_{3}$ and $\mathrm{HClO}_{4}(4: 1, \mathrm{v} / \mathrm{v})$ at $260{ }^{\circ} \mathrm{C}$. The $\mathrm{Cd}, \mathrm{Zn}$, and Fe content was measured using an inductively coupled plasma mass spectrometer (7900, Agilent, Santa Clara, CA, USA). The reference standard solutions of Cd, $\mathrm{Zn}$, and Fe were purchased from the Guobiao Testing and Certification Company (Beijing, China). The translocation factor (TF) was calculated as the shoot-to-root metal content ratio.

Analysis of subcellular distribution of $\mathbf{C d}$ and $\mathrm{Zn}$ : The subcellular distribution of $\mathrm{Cd}$ and $\mathrm{Zn}$ was measured as described by Wang et al. (2009) and Lai (2015). Briefly, ground powder ( $1 \mathrm{~g}$ fresh mass) was centrifuged in precooling extraction buffer $[50 \mathrm{mM}$ Tris- $\mathrm{HCl}(\mathrm{pH} 7.5)$, $250 \mathrm{mM}$ sucrose and $1.0 \mathrm{mM}$ dithiothreitol $\left.\left(\mathrm{C}_{4} \mathrm{H}_{10} \mathrm{O}_{2} \mathrm{~S}_{2}\right)\right]$. Three fractions, namely the cell wall fraction $\left(\mathrm{F}_{\mathrm{CW}}\right)$, the organelles fraction $\left(\mathrm{F}_{\mathrm{CO}}\right)$, and the soluble fraction (including vacuoles; $\mathrm{F}_{\mathrm{CS}}$ ), were extracted via different centrifugations. The $\mathrm{Cd}$ and $\mathrm{Zn}$ content in the different fractions were measured as described in the preceding section.

Cadmium chemical forms: The $\mathrm{Cd}$ chemical forms were analyzed following the method described by $\mathrm{Wu}$ et al. (2005) and Cheng et al. (2018). Six chemical forms of Cd were differentiated: inorganic $\mathrm{Cd}$ (the fraction extracted by ethanol, $\mathrm{F}_{\mathrm{E}}$ ), water-soluble $\mathrm{Cd}$ (the fraction extracted by water, $\mathrm{F}_{\mathrm{W}}$ ), pectate- and protein-integrated $\mathrm{Cd}$ (the fraction extracted by $\mathrm{NaCl}, \mathrm{F}_{\mathrm{NaCl}}$ ), undissolved $\mathrm{Cd}$ phosphate [the fraction extracted by acetic acid (HAc) $\mathrm{F}_{\mathrm{HAc}}$, Cd oxalate (the fraction extracted by $\mathrm{HCl}, \mathrm{F}_{\mathrm{HCl}}$ ), and residual $\mathrm{Cd}$ (the fraction of residual $\mathrm{Cd}, \mathrm{F}_{\mathrm{R}}$ ). The $\mathrm{Cd}$ content in each extract was measured using the afore-mentioned procedure.

Analysis of ${ }^{15} \mathbf{N}$ and total $\mathbf{N}$ content: The ${ }^{15} \mathrm{~N}$ and total $\mathrm{N}$ content was determined in accordance with the method 
of Preston and Owens (1983) using an isotope ratio mass spectrometer (Delta V Advantage, Thermo Fisher Scientific, Waltham, MA, USA) at the Graduate School of Tsinghua University (ShenZhen, China). Briefly, dried ground powder $(2 \mathrm{mg})$ of each sample was calcined at a high temperature in the elemental analyzer. The ${ }^{15} \mathrm{~N}$ concentration was calculated by comparison with the international nitrogen standard (Mariotti 1984).

Analysis of gene expression: Gene expression was analyzed using the RNA sequencing (RNA-Seq) method described by Wang et al. (2017b). The RNA-Seq procedure, including RNA isolation, library construction and sequencing, transcriptome assembly, gene functional annotation, and differential expression analysis, was conducted at the Novogene Bioinformatics Institute (Beijing, China). Read counts of each gene were converted into reads per kilobase per million values to normalize the gene expression (Mortazavi et al. 2008). Differentially expressed genes were determined using the DEseq method (Ander and Huber 2010). The threshold value of $\log _{2}$ fold change $>1$ or $<-1$ with $P<0.0005$ was employed to assess the significance of differential expression.

Statistical analysis: The significance of differences among means was statistically analyzed using Duncan's multiple range test implemented in the IBM SPSS Statistics v. 20.0 software (IBM Corporation, Armonk, NY, USA) using the $5 \%$ level of significance. All graphics were plotted using Sigmaplot 12.0 software (Systat Software, San Jose, CA, USA).

\section{Results}

All plants look well during the experimental period, although root growth was differentially affected by the treatments (Fig. 1A). Without $\mathrm{Cd}$ or $\mathrm{Zn}$ stress, the high concentration of $\mathrm{Ca}-\mathrm{K}$ reduced root length. Under the low concentration of $\mathrm{Ca}-\mathrm{K}$, all $\mathrm{Cd}$ and $\mathrm{Zn}$ stresses reduced root length compared with that of the CK (Fig. 1A). Under the high concentration of $\mathrm{Ca}-\mathrm{K}, \mathrm{Cd}$ and $\mathrm{Cd}+\mathrm{Zn}$ dramatically reduced root length, whereas $\mathrm{Zn}$ did not affect root length, compared with that of the CK (Fig. 1A). All stress treatments did not change shoot length (Fig. 1B), which might be resulted from the fact that various treatments were not severely stressful.

Compared with the low concentration of $\mathrm{Ca}-\mathrm{K}$, the high concentration of $\mathrm{Ca}-\mathrm{K}$ reduced the $\mathrm{Cd}$ content in roots (Fig. 2A) and increased the $\mathrm{Cd}$ content in shoots under Cd stress (Fig. 2B). The $\mathrm{Zn}$ content in roots and shoots were even reduced under $\mathrm{Zn}$ stress (Fig. 2C,D), and the $\mathrm{Cd}$ and $\mathrm{Zn}$ content was reduced in roots but remained unchanged in shoots under $\mathrm{Cd}+\mathrm{Zn}$ stress due to high $\mathrm{Ca}-\mathrm{K}$ concentration (Fig. 2A-D). Under low concentration of Ca-K, $\mathrm{Zn}$ reduced the $\mathrm{Cd}$ content in roots by $65.0 \%$ (Fig. $2 \mathrm{~A}$ ), but increased the $\mathrm{Cd}$ content in shoots under $\mathrm{Cd}+\mathrm{Zn}$ stress when compared with that under $\mathrm{Cd}$ stress (Fig. $2 B$ ); however, $\mathrm{Cd}$ increased the $\mathrm{Zn}$ content in roots (Fig. $2 C)$, but reduced the $\mathrm{Zn}$ content in shoots under $\mathrm{Cd}+\mathrm{Zn}$ stress when compared with that under Zn stress (Fig. 2D). Under the high concentration of $\mathrm{Ca}-\mathrm{K}, \mathrm{Zn}$ reduced the $\mathrm{Cd}$ content in roots by $50.0 \%$ (Fig. $2 A$ ), but increased it in shoots under $\mathrm{Cd}+\mathrm{Zn}$ stress when compared with that under $\mathrm{Cd}$ stress (Fig. 2B); however, Cd increased the $\mathrm{Zn}$ content in roots (Fig. 2C), but did not affect it in shoots under $\mathrm{Cd}+\mathrm{Zn}$ stress when compared with $\mathrm{Zn}$ stress (Fig. 2D).

Without $\mathrm{Cd}$ or $\mathrm{Zn}$ stress, the high concentration of $\mathrm{Ca}-\mathrm{K}$ increased the $\mathrm{Fe}$ content in roots and shoots when compared with that under the low concentration of $\mathrm{Ca}-\mathrm{K}$ (Fig. 2E,F). Under the low concentration of $\mathrm{Ca}-\mathrm{K}, \mathrm{Cd}$ increased the $\mathrm{Fe}$ content in roots, but $\mathrm{Zn}$ and $\mathrm{Cd}+\mathrm{Zn}$ reduced the Fe content when compared with that of the $\mathrm{CK}$ (Fig. 2E); only $\mathrm{Cd}+\mathrm{Zn}$ reduced the $\mathrm{Fe}$ content in shoots (Fig. 2F). Under the high concentration of Ca-K, only $\mathrm{Zn}$ reduced the Fe content in roots and shoots when compared with that of the CK (Fig. 2E,F). Compared with the low concentration of $\mathrm{Ca}-\mathrm{K}$, the high concentration of $\mathrm{Ca}-\mathrm{K}$ reduced the $\mathrm{Fe}$ content in roots (Fig. $2 E$ ), but increased that in shoots under Cd stress (Fig. $2 F$ ); in addition, the $\mathrm{Fe}$ content in roots and shoots was increased under $\mathrm{Cd}+\mathrm{Zn}$ stress (Fig. 2E,F).

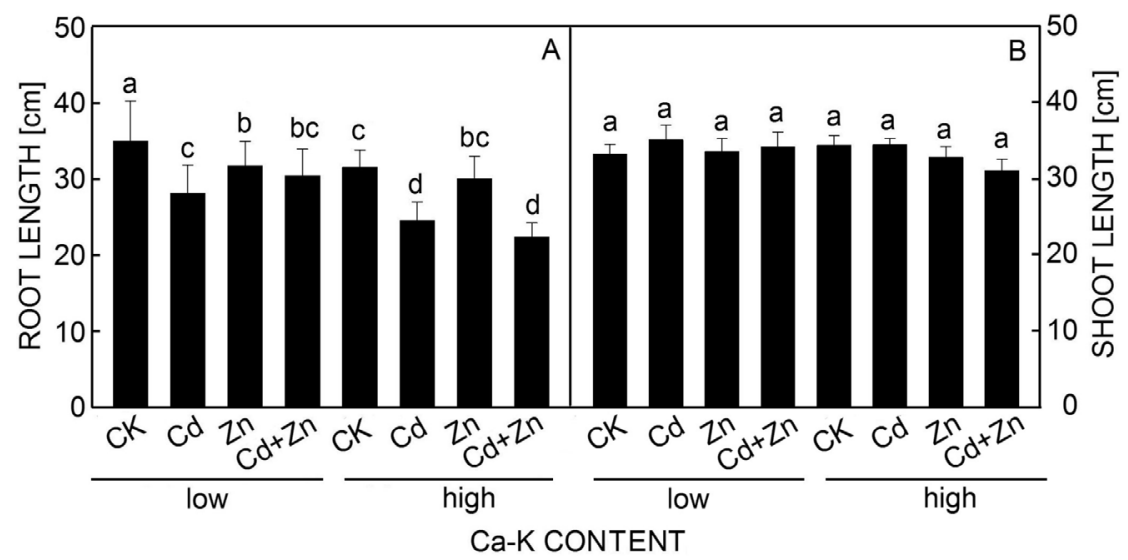

Fig. 1. Root and shoot lengths of seedlings treated with $\mathrm{Cd}, \mathrm{Zn}$, and $\mathrm{Cd}+\mathrm{Zn}$ stresses under a low or high concentration of calcium and potassium. CK - control. Means \pm SEs of 30 plants. The Duncan's multiple range test was used to test the significance of differences among the treatments at $\alpha=0.05$. Different lower-case letters indicate statistically significant differences. 


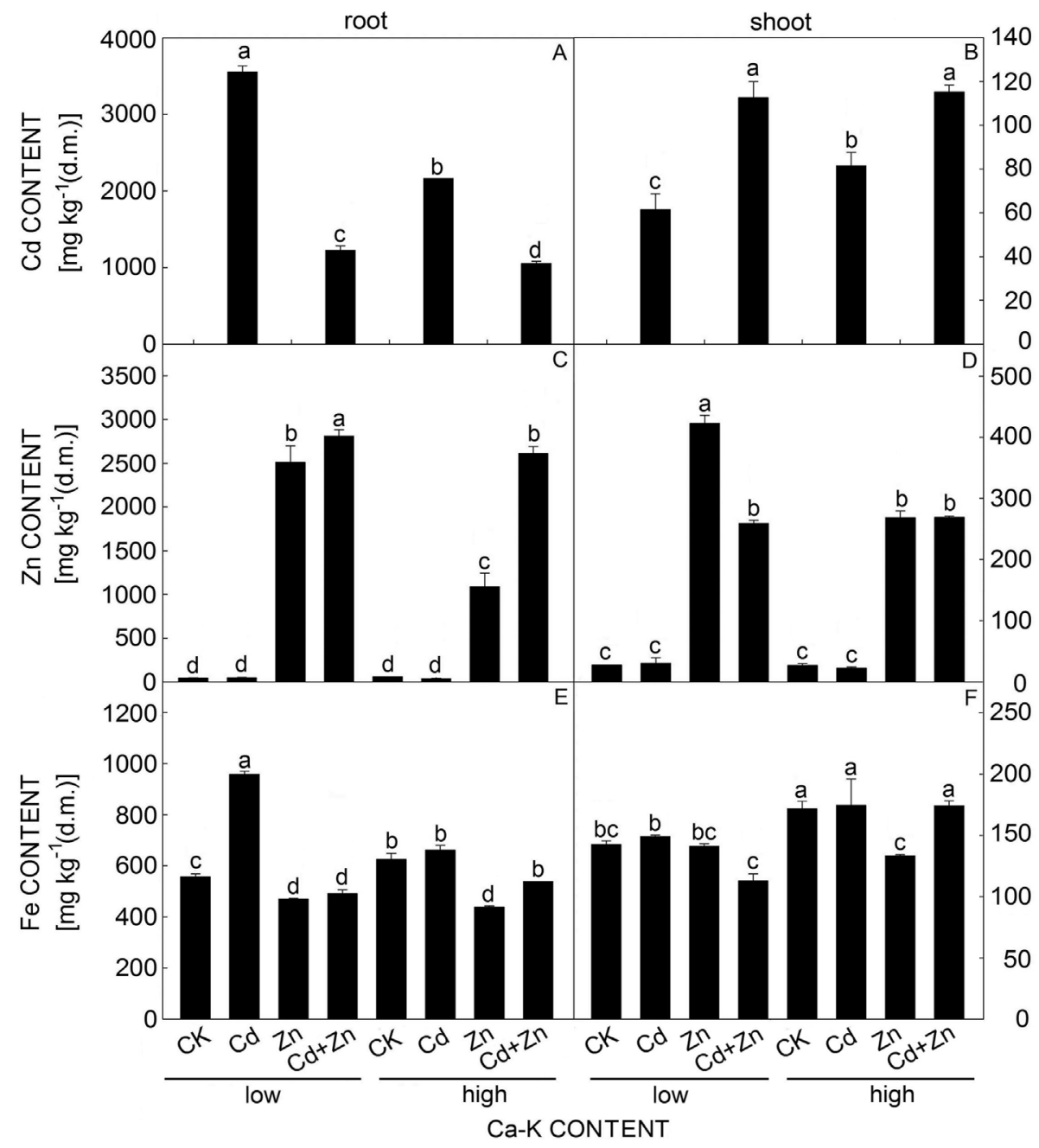

Fig. 2. Metal content in roots and shoots of seedlings treated with $\mathrm{Cd}, \mathrm{Zn}$, and $\mathrm{Cd}+\mathrm{Zn}$ stresses under a low or high concentration calcium and potassium. CK - control. Means \pm SEs of three biological replicates. The Duncan's multiple range test was used to test the significance of differences among the treatments at $\alpha=0.05$. Different lower-case letters indicate statistically significant differences.

Under $\mathrm{Cd}$ and $\mathrm{Cd}+\mathrm{Zn}$ stresses, the high concentration of $\mathrm{Ca}-\mathrm{K}$ increased the $\mathrm{Cd}$ translocation factor compared with that under the low concentration of Ca-K (Fig. $3 A$ ). Compared with that under $\mathrm{Cd}$ stress, $\mathrm{Zn}$ dramatically increased the $\mathrm{Cd} \mathrm{TF}$ under $\mathrm{Cd}+\mathrm{Zn}$ stress; interestingly, the increase was greater under the low concentration of Ca-K (Fig. 3A). Under Zn stress, the high concentration of $\mathrm{Ca}-\mathrm{K}$ increased the $\mathrm{Zn} \mathrm{TF}$ compared with that under the low concentration of $\mathrm{Ca}-\mathrm{K}$ (Fig. $3 B$ ). Under $\mathrm{Cd}+\mathrm{Zn}$ stress, the high concentration of $\mathrm{Ca}-\mathrm{K}$ did not affect the $\mathrm{Zn}$ TF (Fig. 3B). Compared with that under $\mathrm{Zn}$ stress, Cd reduced the $\mathrm{Zn}$ TF under $\mathrm{Cd}+\mathrm{Zn}$ stress; the reduction in the $\mathrm{Zn}$ TF was greater under the high concentration of Ca-K (Fig. 3B).

The concentration of $\mathrm{Ca}-\mathrm{K}$ influenced the uptake and translocation of $\mathrm{Cd}$ and $\mathrm{Zn}$, which would result from changes in the subcellular distribution of $\mathrm{Cd}$ and $\mathrm{Zn}$. In roots, the majority of $\mathrm{Cd}$ was bound in the cell wall fraction (Fig. 4A); in shoots, Cd was mainly bound in the cell wall and soluble fractions (Fig. $4 B$ ). Under Cd stress, the high concentration of $\mathrm{Ca}-\mathrm{K}$ reduced the $\mathrm{Cd}$ content in the root cell wall (Fig. $4 A$ ) and shoot soluble fraction (Fig. $4 B$ ). Under $\mathrm{Cd}+\mathrm{Zn}$ stress, the high concentration of $\mathrm{Ca}-\mathrm{K}$ reduced the $\mathrm{Cd}$ content of the root cell wall and soluble fractions (Fig. 4A) and the shoot soluble fraction (Fig. 4B). Compared with that under Cd stress, $\mathrm{Zn}$ remarkably decreased the $\mathrm{Cd}$ content of the root cell wall (Fig. 4A), and increased that of the root soluble fraction and shoot cell wall, soluble and organelle fractions under $\mathrm{Cd}+\mathrm{Zn}$ stress in conjunction with the low concentration of $\mathrm{Ca}-\mathrm{K}$ (Fig. $4 B$ ); in addition, $\mathrm{Zn}$ reduced the $\mathrm{Cd}$ content of the root cell wall (Fig. 4A), and increased that of the shoot soluble fraction under $\mathrm{Cd}+\mathrm{Zn}$ stress in conjunction with the high concentration of Ca-K (Fig. 4B).

In roots and shoots, $\mathrm{Zn}$ was mainly bound in the cell wall fraction. Under $\mathrm{Zn}$ stress, the high concentration of $\mathrm{Ca}-\mathrm{K}$ reduced the $\mathrm{Zn}$ content in cell wall and soluble fractions in roots and shoots compared with those under the low concentration of $\mathrm{Ca}-\mathrm{K}$ (Fig. 4C,D). Under $\mathrm{Cd}+\mathrm{Zn}$ stress, the high concentration of $\mathrm{C}-\mathrm{K}$ reduced the $\mathrm{Zn}$ content in the root soluble fraction (Fig. $4 C$ ), and increased that of the shoot cell wall (Fig. 4D). Compared with $\mathrm{Zn}$ stress, 


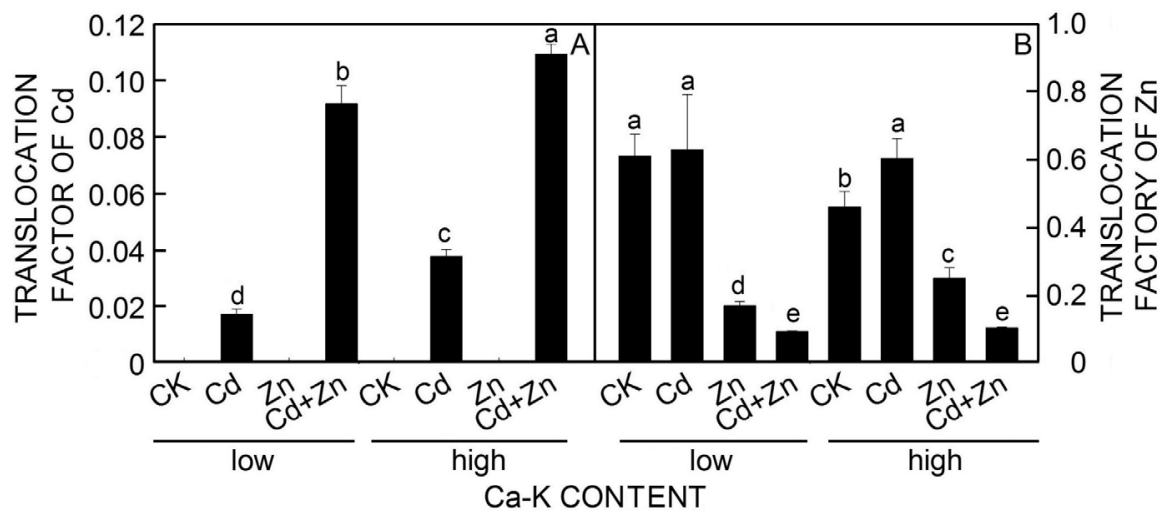

Fig. 3. Translocation factors for $\mathrm{Cd}$ and $\mathrm{Zn}$ of seedlings treated with $\mathrm{Cd}, \mathrm{Zn}$, and $\mathrm{Cd}+\mathrm{Zn}$ stresses under a low or high concentration of calcium and potassium. CK - control. Means \pm SEs of three biological replicates. The Duncan's multiple range test was used to test the significance of differences among the treatments at $\alpha=0.05$. Different lower-case letters indicate statistically significant differences.

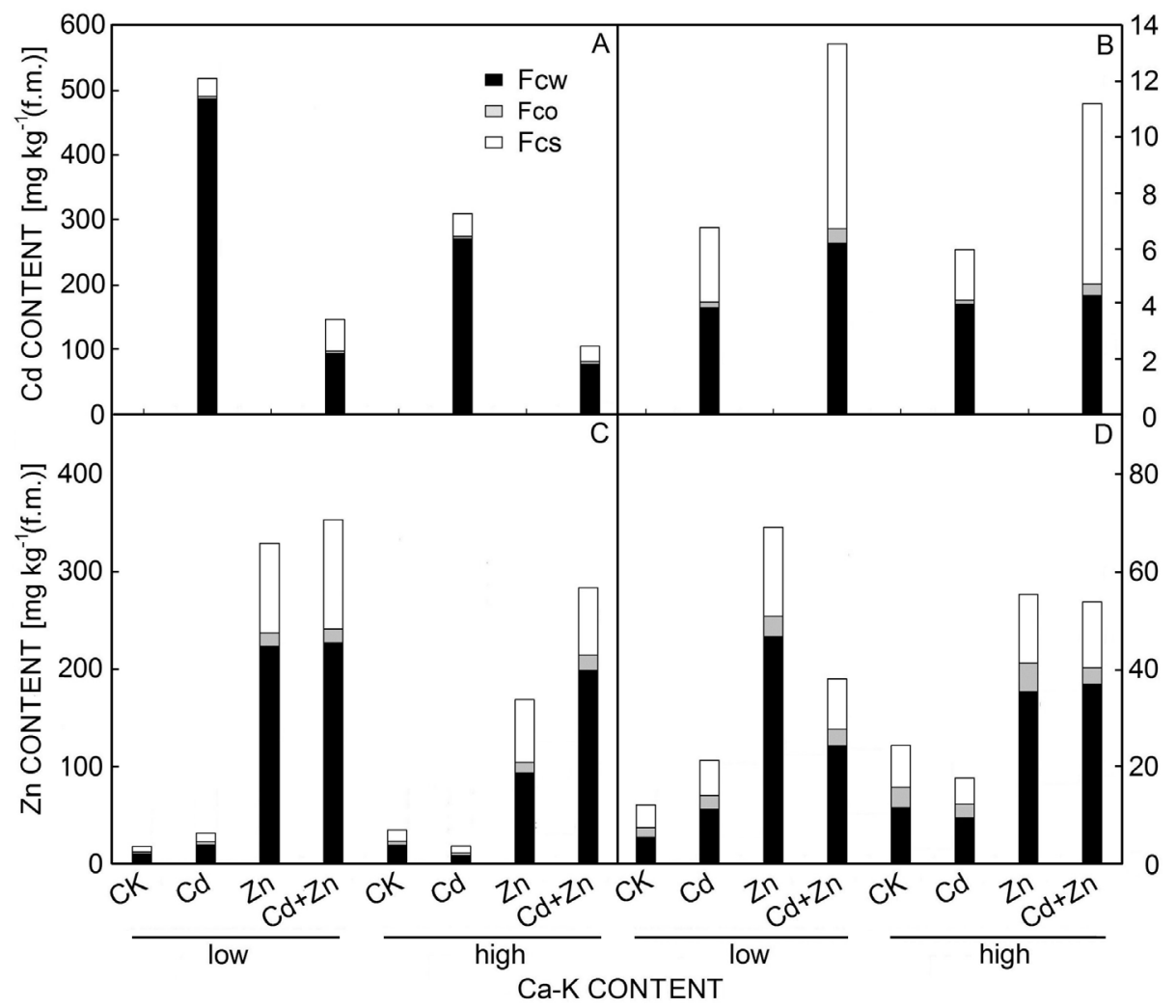

Fig. 4. Subcellular distribution of $\mathrm{Cd}$ and $\mathrm{Zn}$ in roots $(A, C)$ and shoots $(B, D)$ of seedlings treated with $\mathrm{Cd}, \mathrm{Zn}$, and $\mathrm{Cd}+\mathrm{Zn}$ stresses under a low or high concentration of calcium and potassium. $\mathrm{CK}$ - control, $\mathrm{F}_{\mathrm{CW}}$ - cell wall fraction, $\mathrm{F}_{\mathrm{CO}}$ - organelle fraction, $\mathrm{F}_{\mathrm{CS}}-$ soluble fraction. Means of three biological replicates.

Cd did not change the $\mathrm{Zn}$ content of the root cell wall, but increased that of the root soluble fraction (Fig. 4C) and reduced that of the shoot cell wall and soluble fractions under $\mathrm{Cd}+\mathrm{Zn}$ stress under the low concentration of $\mathrm{Ca}-\mathrm{K}$ (Fig. 4D). Under the high concentration of $\mathrm{Ca}-\mathrm{K}, \mathrm{Cd}$ significantly increased the $\mathrm{Zn}$ content of the root cell wall (Fig. 4C), and reduced that of the shoot cell organelles under $\mathrm{Cd}+\mathrm{Zn}$ stress compared with that under $\mathrm{Zn}$ stress (Fig. 4D).

Given that $\mathrm{Ca}-\mathrm{K}$ and $\mathrm{Zn}$ differentially influenced the uptake, translocation, and subcellular distribution of $\mathrm{Cd}$, we investigated whether $\mathrm{Ca}-\mathrm{K}$ and $\mathrm{Zn}$ differentially affected the $\mathrm{Cd}$ chemical forms Under Cd stress, the high concentration of $\mathrm{Ca}-\mathrm{K}$ enhanced the root wall fraction (Table 1) and the shoot $\mathrm{F}_{\mathrm{W}}, \mathrm{F}_{\mathrm{NaCl}}$, and $\mathrm{F}_{\mathrm{R}}$ (Table 2), but reduced the root $F_{\mathrm{HAC}}$ (Table 1) and the shoot $\mathrm{F}_{\mathrm{E}}$ and $\mathrm{F}_{\mathrm{HAC}}$ (Table 2). Under $\mathrm{Cd}+\mathrm{Zn}$ stress, the high concentration of Ca-K enhanced the root $\mathrm{F}_{\mathrm{NaCl}}, \mathrm{F}_{\mathrm{HAC}}$, and $\mathrm{F}_{\mathrm{R}}$ (Table 1), but reduced the shoot $F_{E}, F_{W}, F_{H A C}$, and $F_{R}$ (Table 2). Under the low concentration of $\mathrm{Ca}-\mathrm{K}, \mathrm{Zn}$ increased the root $\mathrm{F}_{\mathrm{W}}$ and 
Table 1. Chemical forms of $\mathrm{Cd}$ in roots. Cadmium content under control and $\mathrm{Zn}$ stress was below the detection limit.

\begin{tabular}{lcccc}
\hline & \multicolumn{2}{c}{ Low concentration of Ca-K } & \multicolumn{2}{c}{ High concentration of Ca-K } \\
& $\mathrm{Cd}\left[\mathrm{mg} \mathrm{kg}^{-1}\right]$ & $\mathrm{Cd}+\mathrm{Zn}\left[\mathrm{mg} \mathrm{kg}^{-1}\right]$ & $\mathrm{Cd}\left[\mathrm{mg} \mathrm{kg}^{-1}\right]$ & $\mathrm{Cd}+\mathrm{Zn}\left(\left[\mathrm{g} \mathrm{kg}^{-1}\right]\right.$ \\
\hline Fraction extracted by ethanol & $9.30 \pm 0.32$ & $0.54 \pm 0.08$ & $8.74 \pm 1.68$ & $0.85 \pm 0.11$ \\
Fraction extracted by water & $7.97 \pm 0.88$ & $18.34 \pm 1.82$ & $14.82 \pm 3.02$ & $13.27 \pm 2.22$ \\
Fraction extracted by NaCl & $26.08 \pm 1.32$ & $13.33 \pm 2.08$ & $31.74 \pm 4.14$ & $22.74 \pm 2.53$ \\
Fraction extracted by HAc & $57.02 \pm 0.32$ & $6.11 \pm 0.15$ & $27.01 \pm 2.90$ & $12.70 \pm 0.03$ \\
Fraction extracted by HCl & $2.00 \pm 0.06$ & $0.67 \pm 0.13$ & $2.18 \pm 0.66$ & $0.59 \pm 0.21$ \\
Fraction of residual Cd & $0.46 \pm 0.11$ & $0.06 \pm 0.00$ & $0.46 \pm 0.03$ & $0.37 \pm 0.02$ \\
\hline
\end{tabular}

Table 2. Chemical forms of $\mathrm{Cd}$ in shoots. Cadmium content under control and $\mathrm{Zn}$ stress was below the detection limit.

\begin{tabular}{lllll}
\hline & \multicolumn{2}{l}{ Low concentration of Ca-K } & \multicolumn{2}{l}{ High concentration of Ca-K } \\
& $\mathrm{Cd}\left[\mathrm{mg} \mathrm{kg}^{-1}\right]$ & $\mathrm{Cd}+\mathrm{Zn}\left[\mathrm{mg} \mathrm{kg}^{-1}\right]$ & $\mathrm{Cd}\left[\mathrm{g} \mathrm{kg}^{-1}\right]$ & $\mathrm{Cd}+\mathrm{Zn}(\mathrm{mg} \mathrm{kg}-1]$ \\
\hline Fraction extracted by ethanol & $0.38 \pm 0.02$ & $0.41 \pm 0.03$ & $0.28 \pm 0.02$ & $0.26 \pm 0.02$ \\
Fraction extracted by water & $0.30 \pm 0.04$ & $0.90 \pm 0.08$ & $0.92 \pm 0.13$ & $0.63 \pm 0.08$ \\
Fraction extracted by NaCl & $0.15 \pm 0.02$ & $0.57 \pm 0.06$ & $0.25 \pm 0.02$ & $0.48 \pm 0.10$ \\
Fraction extracted by HAc & $0.41 \pm 0.09$ & $1.25 \pm 0.17$ & $0.22 \pm 0.01$ & $0.64 \pm 0.06$ \\
Fraction extracted by HCl & $0.20 \pm 0.05$ & $0.21 \pm 0.05$ & $0.28 \pm 0.15$ & $0.18 \pm 0.03$ \\
Fraction of residual Cd & $0.00 \pm \pm 0.03$ & $0.00 \pm 0.01$ & $0.20 \pm 0.02$ & $0.10 \pm 0.01$ \\
\hline
\end{tabular}

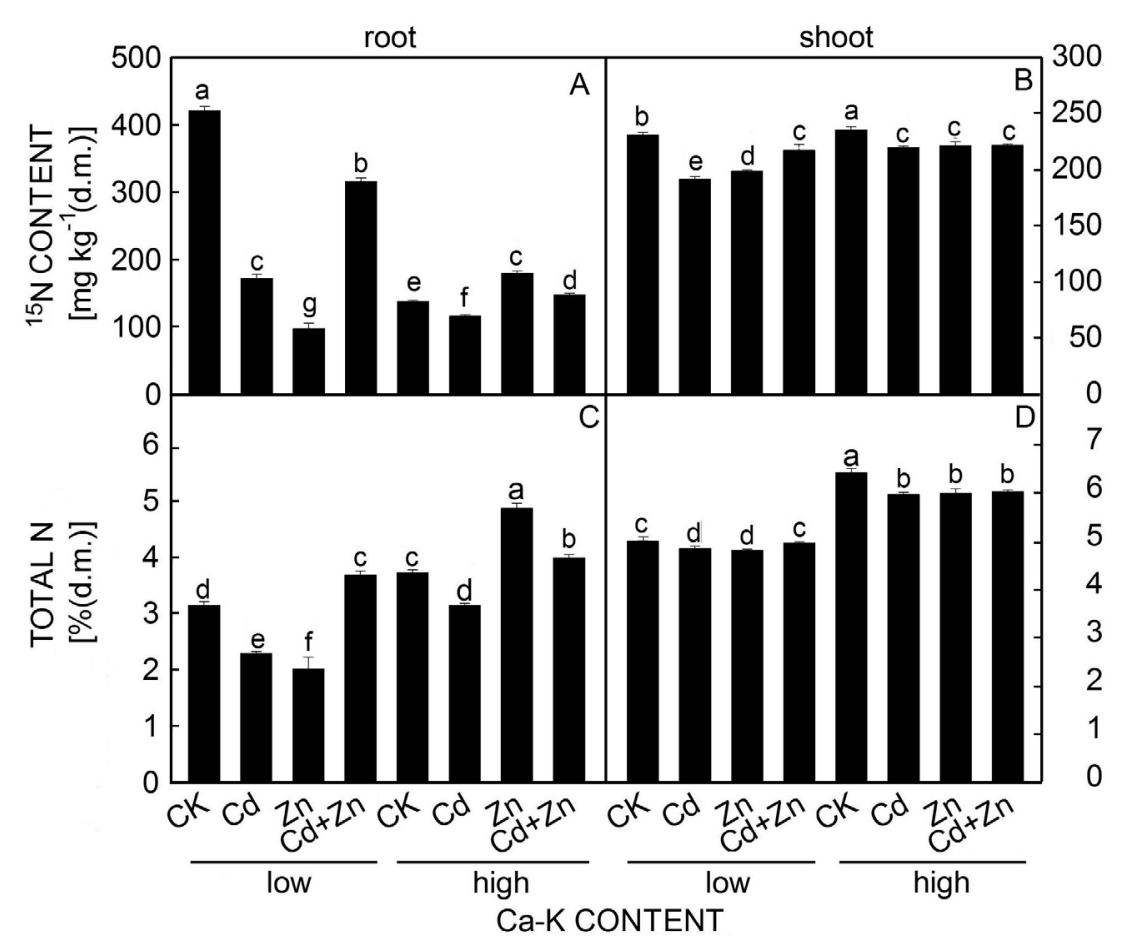

Fig. 5. Nuclide ${ }^{15} \mathrm{~N}$ and total $\mathrm{N}$ content in roots and shoots of seedlings treated with $\mathrm{Cd}, \mathrm{Zn}$, and $\mathrm{Cd}+\mathrm{Zn}$ stresses under a low or high concentration of calcium and potassium. CK - control. Means \pm SEs of three biological replicates. The Duncan's multiple range test was used to test the significance of differences among the treatments at $\alpha=0.05$. Different lower-case letters indicate statistically significant differences.

reduced the root $\mathrm{F}_{\mathrm{E}}, \mathrm{F}_{\mathrm{NaCl}}, \mathrm{F}_{\mathrm{HAC}}, \mathrm{F}_{\mathrm{HCl}}$, and $\mathrm{F}_{\mathrm{R}}$ (Table 1), and also enhanced the shoot $\mathrm{F}_{\mathrm{W}}, \mathrm{F}_{\mathrm{NaCl}}$, and $\mathrm{F}_{\mathrm{HAC}}$ under $\mathrm{Cd}+\mathrm{Zn}$ stress compared with that under Cd stress (Table 2). Under the high concentration of $\mathrm{Ca}-\mathrm{K}, \mathrm{Zn}$ notably reduced the root $\mathrm{F}_{\mathrm{E}}, \mathrm{F}_{\mathrm{NaCl}}, \mathrm{F}_{\mathrm{HAC}}$, and $\mathrm{F}_{\mathrm{HCl}}$ (Table 1), and enhanced the shoot $\mathrm{F}_{\mathrm{NaCl}}$ and $\mathrm{F}_{\mathrm{HAC}}$ under $\mathrm{Cd}+\mathrm{Zn}$ stress compared with 
that under Cd stress (Table 2).

Without $\mathrm{Cd}$ or $\mathrm{Zn}$ stress, the high concentration of $\mathrm{Ca}-\mathrm{K}$ significantly reduced ${ }^{15} \mathrm{~N}$ uptake by roots (Fig. $5 \mathrm{~A}$ ), but did not affect ${ }^{15} \mathrm{~N}$ accumulation in shoots (Fig. $5 B$ ). Under the low concentration of $\mathrm{Ca}-\mathrm{K}, \mathrm{Cd}, \mathrm{Zn}$, and $\mathrm{Cd}+\mathrm{Zn}$ stresses inhibited ${ }^{15} \mathrm{~N}$ uptake by roots (Fig. $5 A$ ) and ${ }^{15} \mathrm{~N}$ accumulation in shoots (Fig. $5 B$ ). Under the high concentration of $\mathrm{Ca}-\mathrm{K}$, $\mathrm{Cd}$ reduced the ${ }^{15} \mathrm{~N}$ content, whereas $\mathrm{Zn}$ and $\mathrm{Cd}+\mathrm{Zn}$ enhanced ${ }^{15} \mathrm{~N}$ accumulation, in roots compared with that of the CK (Fig. $5 A$ ); all metal stresses reduced the ${ }^{15} \mathrm{~N}$ content in shoots (Fig. $5 B$ ). Under $\mathrm{Cd}$ and $\mathrm{Cd}+\mathrm{Zn}$ stresses, the high concentration of $\mathrm{Ca}-\mathrm{K}$ reduced ${ }^{15} \mathrm{~N}$ uptake by roots (Fig. $5 A$ ), but increased ${ }^{15} \mathrm{~N}$ content in shoots only under $\mathrm{Cd}$ stress (Fig. $5 B$ ). Under $\mathrm{Zn}$ stress, the high concentration of $\mathrm{Ca}-\mathrm{K}$ increased the ${ }^{15} \mathrm{~N}$ content in roots (Fig. $5 A$ ) and shoots (Fig. 5B).

In contrast to the results for ${ }^{15} \mathrm{~N}$ uptake and accumulation, the high concentration of Ca-K significantly increased the total $\mathrm{N}$ content in roots (Fig. 5C) and shoots (Fig. 5D) under all stresses compared with those of the individual stresses in conjunction with low concentration of Ca-K. Compared with the CK, Cd and Zn significantly decreased the total $\mathrm{N}$ content in roots and shoots (Fig. 5C,D); whereas $\mathrm{Cd}+\mathrm{Zn}$ increased the total $\mathrm{N}$ content in roots under the low concentration of Ca-K (Fig. 5C). Under the high concentration of $\mathrm{Ca}-\mathrm{K}$, all metal stresses reduced the total $\mathrm{N}$ content in shoots (Fig. 5D); the total $\mathrm{N}$ content in roots was reduced by $\mathrm{Cd}$, but increased by $\mathrm{Zn}$ and $\mathrm{Cd}+\mathrm{Zn}$ compared with that of the $\mathrm{CK}$ (Fig. $5 \mathrm{C}$ ).

The differences in gene expressions were examined using RNA-Seq (Table 1 Suppl.). Under the high concentration of Ca-K, 18 genes involved in polysaccharide hydrolysis, two nitrate transporters 1 (NRT1) 2.6 and 7.2), and one vacuolar iron transporter (VIT) were upregulated by $\mathrm{Cd}$; the expression of these genes was not influenced by $\mathrm{Cd}$ under the low concentration of $\mathrm{Ca}-\mathrm{K}$. Under the low concentration of Ca-K, four genes involved in polysaccharide hydrolysis, three metal transporters, and two NRT1/PTR genes were up-regulated by $\mathrm{Cd}$; however, the expression of these genes was not affected by $\mathrm{Cd}$ under the high concentration of $\mathrm{Ca}-\mathrm{K}$.

Under the high concentration of $\mathrm{Ca}-\mathrm{K}, 11$ genes involved in polysaccharide hydrolysis and Casparian strip establishment, three genes involved in four metal transporters ATP-binding cassette subfamily $B$ member 8 (ABCB8), yellow stripe-like protein (YSL) 6, Zn transporter $(Z T P)$, and $C$ u transporter), eight metal chelation synthesis genes [nicotianamine synthase (NAS) and metallothionein $(M T)$ ], and two NRT1 genes (NRT1 5.10 and 7.2), were up-regulated by $\mathrm{Zn}$. Under the low concentration of Ca-K, 27 genes (13 up- and 14 down-regulated) that participate in polysaccharide synthesis and hydrolysis, and seven metal transporters (VIT, MATE, Ca and Cu transporters) were regulated by $\mathrm{Zn}$.

To investigate how $\mathrm{Ca}-\mathrm{K}$ influenced $\mathrm{Cd} / \mathrm{Zn}$ interactions, we classed the four subgroups including five subgroups. With regard to the $\mathrm{Zn}$ influence on responses to $\mathrm{Cd}$, under the low concentration of $\mathrm{Ca}-\mathrm{K}, 27$ genes involved in polysaccharide synthesis and hydrolysis, 20 metal transporters, one $N A S$ gene, and $11 N R T$ and
$N 4^{+}-N$ transporter genes were up-regulated by $\mathrm{Cd}$, but not by $\mathrm{Cd}+\mathrm{Zn}$ (inhibited by $\mathrm{Zn}$ ). The $\mathrm{Zn}$ inhibition of the regulation of some genes was alleviated by the high concentration of $\mathrm{Ca}-\mathrm{K}$, which including six genes involved in polysaccharide synthesis and hydrolysis, and four metal transporters. Under the high concentration of $\mathrm{Ca}-\mathrm{K}$, eight genes that participated in polysaccharide and chitin hydrolysis, three metal transporters [VIT and two ATP-binding cassette transporters (ABC transporters)], and one $\mathrm{NH}^{+}{ }^{+}-\mathrm{N}$ transporter were up-regulated by $\mathrm{Cd}$, but not by $\mathrm{Cd}+\mathrm{Zn}$ (up-regulation was inhibited by $\mathrm{Zn}$ ).

With regard to the $\mathrm{Cd}$ influence on responses to $\mathrm{Zn}$, under the low concentration of Ca-K, 22 genes involved in polysaccharide hydrolysis and source transport, 10 metal transporters (such as HMA5 and Ca transporter), three metal chelation synthesis genes, and four NRT1 genes were differentially expressed in response to $\mathrm{Zn}$, but not to $\mathrm{Cd}+\mathrm{Zn}$ (inhibited by $\mathrm{Cd}$ ). The inhibition by $\mathrm{Cd}$ of some of these genes was alleviated by the high concentration of $\mathrm{Ca}-\mathrm{K}$, which included the up-regulation of HMA5 and two NRT1/PTR genes. Under the high concentration of Ca-K, four genes that participated in polysaccharide hydrolysis and two NRT1 genes were up-regulated by $\mathrm{Zn}$, but not by $\mathrm{Cd}+\mathrm{Zn}$ (inhibited by $\mathrm{Cd}$ ). Three metal transporters, $16 \mathrm{NAS}$ genes, and two NRT1 genes were up-regulated by $\mathrm{Zn}$ and $\mathrm{Cd}+\mathrm{Zn}$, but not by $\mathrm{Cd}+\mathrm{Zn}$ under the low concentration of Ca-K.

\section{Discussion}

Compared with the low concentration of $\mathrm{Ca}-\mathrm{K}$, the high concentration of $\mathrm{Ca}-\mathrm{K}$ reduced the content of $\mathrm{Cd}$ and $\mathrm{Zn}$ in roots, suggesting that $\mathrm{Ca}-\mathrm{K}$ reduced the uptake of $\mathrm{Cd}$ and $\mathrm{Zn}$. Meanwhile, the TFs of $\mathrm{Cd}$ and $\mathrm{Zn}$ were both increased, which indicated that $\mathrm{Ca}-\mathrm{K}$ promoted the translocation of $\mathrm{Cd}$ and $\mathrm{Zn}$ from roots to shoots. These results differed from the significant reduction in $\mathrm{Cd}$ content in shoots of faba bean and chickpea in response to $\mathrm{Ca}-\mathrm{K}$ treatment (Siddiqui et al. 2012, Ahmad et al. 2016), and the increase in $\mathrm{Cd}$ content in roots and shoots of wheat in response to $\mathrm{K}$ treatment (Zhao et al. 2003). However, $\mathrm{K}$ and $\mathrm{Ca}$ reduce $\mathrm{Cd}$ uptake in soybean and wheat (Yang and Juang 2015). Application of $\mathrm{NO}_{3}^{-}-\mathrm{N}$ promotes the uptake and translocation of $\mathrm{Cd}$ compared with those in the absence of $\mathrm{NO}_{3}{ }^{-}-\mathrm{N}$ (Wang et al. 2019). Thus, the reduced uptake and promoted translocation of $\mathrm{Cd}$ were caused by a high concentration of $\mathrm{Ca}-\mathrm{K}$.

In chickpea and faba bean, a high concentration of $\mathrm{Ca}-\mathrm{K}$ restores the root and shoot growth retarded by $\mathrm{Cd}$ stress, and reduces the $\mathrm{Cd}$ content in roots and shoots (Siddiqui et al. 2012, Ahmad et al. 2016), which implies that the reduced $\mathrm{Cd}$ content was probably diluted by the increased biomass. In the present study, although the high concentration of $\mathrm{Ca}-\mathrm{K}$ significantly reduced the uptake of $\mathrm{Cd}$ and $\mathrm{Zn}$ in roots, it also notably reduced the root length under $\mathrm{Cd}$ and $\mathrm{Zn}$ stresses. Thus, the reduced uptake of $\mathrm{Cd}$ and $\mathrm{Zn}$ in response to $\mathrm{Ca}-\mathrm{K}$ was mediated through reduction in the capacity of the roots to acquire $\mathrm{Cd}$ and $\mathrm{Zn}$, which would be supported by changes in gene expression, 
$\mathrm{Cd}$ and $\mathrm{Zn}$ subcellular distribution, chemical forms of $\mathrm{Cd}$, and $\mathrm{N}$ content.

Uptake and transport of $\mathrm{Cd}$ and $\mathrm{Zn}$ are mediated by a series of metal transporters in plants, such as $A B C$, natural resistance-associated macrophage protein (NRAMP), Zn transporter, VIT, and YSL (Curie et al. 2009, Wang et al. 2010, Park et al. 2012, Xu et al. 2015, Connorton et al. 2017). Overexpression of AtABCC1 enhances the $\mathrm{Cd}$ content in roots of Arabidopsis (Park et al. 2012). In the present study, two $A B C$ transporters and one $\mathrm{Cu}$ transporter were up-regulated by $\mathrm{Cd}$ under the low concentration of $\mathrm{Ca}-\mathrm{K}$, but not by $\mathrm{Cd}$ under the high concentration of $\mathrm{Ca}-\mathrm{K}$, which might result in a higher $\mathrm{Cd}$ content in roots under $\mathrm{Cd}$ stress in conjunction with the low concentration of $\mathrm{Ca}-\mathrm{K}$ than that under $\mathrm{Cd}$ stress with the high concentration of Ca-K. Overexpression of TaVIT1 increases the $\mathrm{Zn}$ content in barley (Connorton et al. 2017), which implies that $\mathrm{Zn}$ is sequestrated into the vacuoles $(\mathrm{Li}$ et al. 2001). Thus, the up-regulation of three VIT genes in DPW increased the $\mathrm{Zn}$ content in roots and shoots and in the soluble fraction (including vacuoles) under $\mathrm{Zn}$ stress under the low concentration of $\mathrm{Ca}-\mathrm{K}$, when compared with $\mathrm{Zn}$ stress and the high concentration of $\mathrm{Ca}-\mathrm{K}$. Zinc transporter, ABC transporter, and YSL transport Zn into the cytoplasm (Wang et al. 2010, Xu et al. 2015), which facilitates translocation of $\mathrm{Zn}$ to shoots. Thus, upregulation of these transporters enhanced the $\mathrm{Zn}$ TF under $\mathrm{Zn}$ stress under the high concentration of $\mathrm{Ca}-\mathrm{K}$. Increase in shoot $\mathrm{NO}_{3}^{-}-\mathrm{N}$ uptake enhances $\mathrm{Cd}$ xylem loading and therefore promotes Cd translocation (Li et al. 2010). Under $\mathrm{Cd}$ and $\mathrm{Zn}$ stresses, a high concentration of $\mathrm{Ca}-\mathrm{K}$ would significantly increase the $\mathrm{NO}_{3}{ }^{-}-\mathrm{N}$ content in shoots, which would also account for the enhanced TFs for $\mathrm{Cd}$ and $\mathrm{Zn}$ under the high concentration of $\mathrm{Ca}-\mathrm{K}$ in the present study.

Previous studies indicate that plant cell wall binding and/or vacuole sequestration crucially determines the acquisition capacity for $\mathrm{Cd}$ and $\mathrm{Zn}$ in roots and shoots, and the translocation of $\mathrm{Cd}$ and $\mathrm{Zn}$ from roots to shoots (Xin et al. 2014, Lai 2015, Wang et al. 2015, Cheng et al. 2018). Cell wall polysaccharides, including pectin and hemicellulose, are major binding sites for $\mathrm{Cd}$ and $\mathrm{Zn}$; therefore, degradation of polysaccharides in the cell wall can reduce $\mathrm{Cd}$ and $\mathrm{Zn}$ uptake by roots and promote their translocation to shoots (Han et al. 2014, Li et al. 2015). Compared with the low concentration of $\mathrm{Ca}-\mathrm{K}$, the high concentration of $\mathrm{Ca}-\mathrm{K}$ induced up-regulation of a greater number of genes that participate in polysaccharide hydrolysis in DPW under Cd stress. In contrast, compared with the high concentration of $\mathrm{Ca}-\mathrm{K}$, the low concentration of $\mathrm{Ca}-\mathrm{K}$ resulted in down-regulation of a greater number of genes involved in polysaccharide hydrolysis and upregulation of several genes involved in polysaccharide synthesis under $\mathrm{Zn}$ stress. Thus, the high concentration of $\mathrm{Ca}-\mathrm{K}$ reduced polysaccharide content under $\mathrm{Cd}$ and $\mathrm{Zn}$ stresses compared with that under the low concentration of $\mathrm{Ca}-\mathrm{K}$, thus reducing the $\mathrm{Cd}$ and $\mathrm{Zn}$ content in the root cell wall fractions, and ultimately promoting $\mathrm{Cd}$ and $\mathrm{Zn}$ translocation to shoots. Interestingly, under $\mathrm{Zn}$ stress, the high concentration of $\mathrm{Ca}-\mathrm{K}$ resulted in up-regulation of three genes encoding Casparian strip proteins, which implied that development of the Casparian strips was promoted to reduce Zn entry into roots (Lux et al. 2011).

The Ca-K concentration also affects the $\mathrm{Cd}$ chemical forms, which would influence Cd migration (Lai 2015, Wang et al. 2015). The $\mathrm{F}_{\mathrm{W}}$ fraction shows a greater capability to migrate, which facilitates xylem loading to transport Cd to shoots (Wang et al. 2015). In contrast, the $\mathrm{F}_{\mathrm{HAc}}$ fraction shows a lower migration than $\mathrm{F}_{\mathrm{W}}$, which is mainly bound to the cell wall to limit $\mathrm{Cd}$ translocation (Lai 2015, Wang et al. 2015). Compared with the low concentration of $\mathrm{Ca}-\mathrm{K}$, application of $\mathrm{Ca} / \mathrm{K}$ enhanced root $\mathrm{F}_{\mathrm{W}}$ and reduced root $\mathrm{F}_{\mathrm{HAc}}$, which, therefore, enhanced the $\mathrm{Cd} \mathrm{TF}$, in the present study.

Our present study indicated that $\mathrm{Cd}$ and $\mathrm{Zn}$ uptakes share the same pathways (Cheng et al. 2018), because Zn significantly reduced Cd uptake, whereas Cd dramatically increased Zn uptake. Meanwhile, the high concentration of $\mathrm{Ca}-\mathrm{K}$ alleviated the reduction in $\mathrm{Cd}$ uptake caused by $\mathrm{Zn}$, and reinforced the promotion of $\mathrm{Zn}$ uptake caused by $\mathrm{Cd}$. Compared with $\mathrm{Cd}$ stress, $\mathrm{Cd}+\mathrm{Zn}$ also significantly reduced $\mathrm{Fe}$ uptake under the low concentration of $\mathrm{Ca}-\mathrm{K}$, but did not affect Fe uptake under the high concentration of $\mathrm{Ca}-\mathrm{K}$, suggesting that the reduced $\mathrm{Cd}$ uptake did not promote $\mathrm{Fe}$ uptake under $\mathrm{Cd}+\mathrm{Zn}$ stress. Thus, $\mathrm{Cd}$ uptake does not share the transporters required for Fe uptake. Our previous studies also indicated that two natural resistanceassociated macrophage proteins from DPW may be involved in $\mathrm{Cd}$ uptake, but not in Fe transport (Peng et al. 2018a,b). In contrast, Zn dramatically promoted $\mathrm{Cd}$ translocation, whereas Cd dramatically inhibited $\mathrm{Zn}$ translocation. Furthermore, the high concentration of $\mathrm{Ca}-\mathrm{K}$ alleviated the promotion of $\mathrm{Cd}$ translocation caused by $\mathrm{Zn}$, and reinforced the inhibition of $\mathrm{Zn}$ translocation caused by $\mathrm{Cd}$. These results implied that reduced $\mathrm{Zn}$ translocation promoted $\mathrm{Cd}$ translocation. Thus, $\mathrm{Cd}$ translocation may share the transporters that participate in $\mathrm{Zn}$ translocation.

Under the low and high concentrations of $\mathrm{Ca}-\mathrm{K}$, different $A B C$ transporters were up-regulated by $\mathrm{Cd}$, which indicated that $\mathrm{Cd}$ was taken up by $\mathrm{ABC}$ transporters in roots (Park et al. 2012). However, up-regulation of these genes was inhibited by $\mathrm{Zn}$ under $\mathrm{Cd}+\mathrm{Zn}$ stress, which suggested that $\mathrm{Zn}$ reduced $\mathrm{Cd}$ uptake. A number of $A B C$ transporters up-regulated by $\mathrm{Cd}$ were inhibited by $\mathrm{Cd}+\mathrm{Zn}$ under the low concentration of $\mathrm{Ca}-\mathrm{K}$, but were up-regulated by $\mathrm{Cd}+\mathrm{Zn}$ under the high concentration of $\mathrm{Ca}-\mathrm{K}$. Thus, the high concentration of $\mathrm{Ca}-\mathrm{K}$ alleviated the reduction of $\mathrm{Cd}$ uptake caused by $\mathrm{Zn}$. In rice, overexpression of OSHMA2 increased Cd uptake by roots and reduced $\mathrm{Cd}$ accumulation in shoots (Takahashi et al. 2012). Under the low concentration of Ca-K in DPW, a $H M A 2$ gene was up-regulated by $\mathrm{Cd}$, but the up-regulation was inhibited by $\mathrm{Zn}$ under $\mathrm{Cd}+\mathrm{Zn}$ stress, suggesting one mechanism by which $\mathrm{Zn}$ reduced Cd uptake and promoted $\mathrm{Cd}$ translocation. In addition, $\mathrm{Zn}$ and $\mathrm{Fe}$ transporters play crucial roles in Fe uptake and transport (Evens et al. 2017). Under the low concentration of Ca-K, in DPW several Zn and $\mathrm{Fe}$ transporters were up-regulated by $\mathrm{Cd}$, but not by $\mathrm{Cd}+\mathrm{Zn}$, which indicated that $\mathrm{Cd}$ promoted $\mathrm{Fe}$ uptake to alleviate Cd toxicity (Wu et al. 2012).

In addition, $\mathrm{Ca}-\mathrm{K}$ and $\mathrm{Zn}$ also influenced polysaccharide 
metabolism of root and shoot cell walls and the chemical forms of $\mathrm{Cd}$, which determines the capacity to acquire $\mathrm{Cd}$ as well as its removability (Xin et al. 2014, Lai, 2015, Wang et al. 2015, Cheng et al. 2018). Under the low and high concentrations of $\mathrm{Ca}-\mathrm{K}$, numerous genes involved in polysaccharide synthesis and hydrolysis were regulated by $\mathrm{Cd}$; however, expression of these genes was not inhibited by Zn. Compared with that under Cd stress, Zn significantly reduced the $\mathrm{Cd}$ content in the cell wall fraction under $\mathrm{Cd}+\mathrm{Zn}$ stress. In addition, $\mathrm{Zn}$ significantly reduced the $\mathrm{Cd}$ content in root $\mathrm{F}_{\mathrm{NaCl}}$ and $\mathrm{F}_{\mathrm{HAc}}$, which show lower migration and are mainly bound in the cell wall unclear (Lai 2015, Wang et al. 2015). These results indicated that $\mathrm{Zn}$ reduced the $\mathrm{Cd}$ acquisition capacity of roots and thereby inhibited $\mathrm{Cd}$ uptake. In addition, $\mathrm{Zn}$ increased the $\mathrm{Cd}$ content in the cell wall fraction and soluble fraction (including vacuoles) in shoots, regardless of the supply of Ca-K. Thus, Zn increased the acquisition capacity for $\mathrm{Cd}$ in shoots, and ultimately enhanced $\mathrm{Cd}$ translocation to shoots and the $\mathrm{Cd}$ content in shoots (Cheng et al. 2018). Under Cd+Zn stress, although some inhibitory effects caused by $\mathrm{Zn}$ under the low concentration of $\mathrm{Ca}-\mathrm{K}$ were overcome under the high concentration of $\mathrm{Ca}-\mathrm{K}$, the high concentration of $\mathrm{Ca}-\mathrm{K}$ reduced the $\mathrm{Cd}$ content in the root cell wall fraction and soluble fraction, thus reducing the capacity of roots to inhibit $\mathrm{Cd}$ uptake. Interestingly, the high concentration of $\mathrm{Ca}-\mathrm{K}$ increased the $\mathrm{Cd}$ content of root $\mathrm{F}_{\mathrm{NaCl}}$ and $\mathrm{F}_{\mathrm{HAc}}$, which implies that the high concentration of $\mathrm{Ca}-\mathrm{K}$ reduced $\mathrm{Cd}$ translocation. In contrast, it enhanced $\mathrm{Cd}$ translocation under $\mathrm{Cd}+\mathrm{Zn}$ stress compared with that under $\mathrm{Cd}+\mathrm{Zn}$ stress with the low concentration of $\mathrm{Ca}-\mathrm{K}$, which may indicate that passive transport through the apoplast (i.e., the cell wall) is involved in the transport of Cd from the root to the shoot (Zhao et al. 2010, Li et al. 2017).

$\mathrm{Ca}-\mathrm{K}$ and $\mathrm{Cd}$ also regulated expression of a number of metal transporters, and influenced cell wall metabolism and the subcellular distribution of $\mathrm{Zn}$ to mediate $\mathrm{Zn}$ uptake and transport. Under the low concentration of Ca-K, several VIT genes were up-regulated by $\mathrm{Zn}$ in roots but not by $\mathrm{Cd}+\mathrm{Zn}$. In rice, OsVITs sequestrate $\mathrm{Zn}$ into vacuoles to reduce $\mathrm{Zn}$ translocation (Zhang et al. 2012). Up-regulation of these genes decreased the $\mathrm{Zn}$ content in roots and in root cell vacuoles, and enhanced $\mathrm{Zn}$ translocation, which is consistent with the up-regulation of HMA5 that promotes metal translocation to shoots (Wang et al. 2018). Since $\mathrm{Cd}$ did not influence the $\mathrm{Zn}$ content in the root cell wall fraction, the reduction in $\mathrm{Zn}$ translocation under $\mathrm{Cd}+\mathrm{Zn}$ stress resulted from the increased $\mathrm{Zn}$ content in the root soluble fraction. Under the high concentration of Ca-K, several genes that participate in polysaccharide hydrolysis were up-regulated by $\mathrm{Zn}$ but not by $\mathrm{Cd}+\mathrm{Zn}$. Thus, $\mathrm{Cd}$ increased the availability of binding sites for $\mathrm{Zn}$ under $\mathrm{Cd}+\mathrm{Zn}$ stress compared with that under $\mathrm{Zn}$ stress, and consequently enhanced the $\mathrm{Zn}$ content in the root cell wall to increase $\mathrm{Zn}$ uptake and to reduce $\mathrm{Zn}$ translocation. In addition, under $\mathrm{Cd}+\mathrm{Zn}$ stress, supply of exogenous $\mathrm{Cd} / \mathrm{K}$ reduced the $\mathrm{Zn}$ content in the root cell wall fraction and soluble fraction, which reduced the $\mathrm{Zn}$ acquisition capacity of roots and $\mathrm{Zn}$ uptake.

In summary, our results reveal that application of
Ca-K changed gene expression, $\mathrm{Cd}$ and $\mathrm{Zn}$ subcellular distribution, chemical forms of $\mathrm{Cd}$, and then influenced the $\mathrm{Cd}$ and $\mathrm{Zn}$ uptakes and translocations.

\section{References}

Ahmad, P., Abdel Latef, A.A., Abd-Allah, E.F., Hashem, A., Sarwat, M., Anjum, N.A., Gucel, S.: Calcium and potassium supplementation enhanced growth, osmolyte secondary metabolite production, and enzymatic antioxidant machinery in cadmium-exposed chichpea (Cicer arietinum L.). - Front. Plant Sci. 7: 513, 2016.

Ander, S., Huber, W.: Differential expression analysis for sequence count data. - Genome Biol. 11: R106, 2010.

Cheng, Y., Wang, C., Chai, S., Shuai, W., Sha, L., Zhang, H., Kang, H., Fan, X., Zeng, J., Zhou, Y., Wang, Y.: Ammonium $\mathrm{N}$ influences the uptakes, translocations, subcellular distributions and chemical forms of $\mathrm{Cd}$ and $\mathrm{Zn}$ to mediate the $\mathrm{Cd} / \mathrm{Zn}$ interactions in dwarf polish wheat (Triticum polonicum L.) seedlings. - Chemosphere 193: 1164-1171, 2018.

Clemens, S.: Toxic metal accumulation, responses to exposure and mechanisms of tolerance in plants. - Biochimie 88: 1707$1719,2006$.

Connorton, J.M., Jones, E.R., Rodríguez-Ramiro, I., Fairweather Tait, S., Uauy, C., Balk, J.: Wheat vacuolar iron transporter TaVIT2 transports $\mathrm{Fe}$ and $\mathrm{Mn}$ and is effective for biofortification. - Plant Physiol. 174: 2434-2444, 2017.

Curie, C., Cassin, G., Couch, D., Divol, F., Higuchi, K., Jean, M.L., Misson, J., Schikora, A., Czernic, P., Mari, S.: Metal movement within the plant: contribution of nicotianamine and yeallow stripe 1-like transporters. - Ann. Bot. 103: 1-11, 2009.

Evens, N.P., Buchner, P., Williams, L.E., Hawkesford, M.J.: The role of ZIP transporters and group F bZIP transcription factors in the Zn-deficiency response of wheat (Triticum aestivum). Plant J. 92: 291-304, 2017.

Han, Y., Sa, G., Sun, J., Shen, Z., Zhao, R., Ding, M., Deng, S., Lu, Y., Zhang, Y., Shen, X., Chen, S.: Overexpression of Populus euphratica xyloglucan endotransglucosylase/ hydrolase gene confers enhanced cadmium tolerance by the restriction of root cadmium uptake in transgenic tobacco. Environ. exp. Bot. 100: 74-83, 2014.

Hart, J., Welch, R.M., Norvell, W.A., Clarke, J.M., Kochian, L.V.: Zinc effects on cadmium accumulation and partitioning in near-isogenic lines of durum wheat that differ in grain cadmium concentration. - New Phytol. 167: 391-401, 2005.

Hart, J., Welch, R.M., Norvell, W.A., Kochian, L.V.: Transport interactions between cadmium and zinc in roots of bread and durum wheat seedlings. - Physiol. Plant. 116: 73-78, 2002.

Kobayashi, T., Nishizawa, N,K.: Iron uptake, translocation and regulation in higher plants. - Annu. Rev. Plant Biol. 63: 131152,2012

Lai, H.: Subcellular distribution and chemical forms of cadmium in Impatiens walleriana in relation to its phytoextraction potential. - Chemosphere 138: 370-376, 2015.

Li, H., Luo, N., Li, Y., Cai, Q., Li, H., Mo, C., Wong, M.: Cadmium in rice: transport mechanisms, influencing factors, and minimizing measures. - Environ. Pollut. 224: 622-630, 2017.

Li, J., Fu, Y., Pike, S., Bao, J., Tian, W., Zhang, Y., Chen, C., Zhang, Y., Li, H., Huang, J., Li, L., Schroeder, J.I., Gassmann, W., Gong, J.: The Arabidopsis nitrate transporter NRT1.8 functions in nitrate removal from the xylem sap and mediates cadmium tolerance. - Plant Cell 22: 1633-1646, 2010.

Li, L., Chen, O.S., McVey Ward, D., Kaplan, J.: CCC1 is a 
transporter that mediates vacuolar iron storage in yeast. - J. biol. Chem. 276: 29515-29519, 2001.

Li, T., Tao, Q., Shohag, M.J.I., Yang, X., Sparks, D.L., Liang, Y.: Root cell wall polysaccharides are involved in cadmium hyperaccumulation in Sedum alfredii. - Plant Soil 389: 387399, 2015.

Lux, A., Martinka, M., Vaculik, M., White, P.J.: Root responses to cadmium in the rhizosphere: a review. - J. exp. Bot. 62: 21-37, 2011.

Mariotti, A.: Natural $15 \mathrm{~N}$ abundance measurements and atmospheric nitrogen standard calibration. - Nature 311: 251252, 1984.

Mortazavi, A., Williams, B.A., McCue, K., Schaeffer, L., Wold, B.: Mapping and quantifying mammalian transcriptomes by RNA-Seq. - Nat. Methods 5: 621-628, 2008.

Nan, Z., Li, J., Zhang, J., Cheng, G.: Cadmium and zinc interactions and their transfer in soil-crop system under actual field conditions. - Sci. total Environ. 285: 187-95, 2002.

Park, J., Song, W., Ko, D., Eom, Y., Hansen, T.H., Schiller, M., Lee, T.G., Martinoia, E., Lee, Y.: The phytochelatin transporters AtABCC1 and AtABCC2 mediate tolerance to cadmium and mercury. - Plant J. 69: 278-288, 2012.

Peng, F., Wang, C., Cheng, Y., Zeng, J., Kang, H., Fan, X., Sha, N., Zhang, H., Zhou, Y., Wang, Y.: Cloning and characterization of TpNRAMP3, a metal transporter from polish wheat (Triticum polonicum L.). - Front. Plant Sci. 9: 1354, 2018b.

Peng, F., Wang, C., Zhu, J., Zeng, J., Kang, H., Fan, X., Sha, L., Zhang, H., Zhou, Y., Wang, Y.: Expression of TpNRAMP5, a metal transporter from Polish wheat (Triticum polonicum L.), enhances the accumulation of $\mathrm{Cd}, \mathrm{Co}$ and $\mathrm{Mn}$ in transgenic Arabidopsis plants. - Planta 247: 1395-1406, 2018 a.

Perrier, F., Yan, B., Candaudap, F., Pokrovsky, O.S., Gourdain, E., Meleard, B., Bussière, S., Coriou, C., Robert, T., Nguyen, C., Corny, J.Y.: Variability in grain cadmium concentration among durum wheat cultivars: impact of aboveground biomass partitioning. - Plant Soil 404: 307-320, 2016.

Preston, T., Owens, N.J.P.: Interfacing an automatic elemental analyser with an isotope ratio mass sepectrometer: the potential for fully automated total nitrogen and nitrogen-15 analysis. - Analyst 108: 971-977, 1983.

Sasaki, A., Yamaji, N., Yokosho, K., Ma, J.F.: Nramp5 is a major transporter responsible for manganese and cadmium uptake in rice. - Plant Cell 24: 2155-2167, 2012.

Sharma, S.S., Dietz, K.J., Mimura, T.: Vacuolar compartmentalization as indispensable component of heavy metal detoxification in plants. - Plant Cell Environ. 39: 1112-1126, 2016.

Siddiqui, M.H., Al-Whaibi, M.H., Sakran, A.M., Basalah, M.O., Ali, H.M.: Effect of calcium and potassium on antioxidant system of Vicia faba L. under cadmium stress. - Int. J. mol. Sci. 13: 6604-6619, 2012.

Song, Z., Duan, C., Guo, L., Yang, Y., Feng, Y., Ma, R., Yu, M.: Potassium contributes to zinc stress tolerance in peach (Prunus persica) seedling by enhancing photosynthesis and the antioxidant defense system. - Genet. mol. Res. 14: 8338$8835,2015$.

Sun, Q., Wang, X., Ding, S., Yuan, X.: Effects of interactions between cadmium and zinc on phytochelation and glutathione production in wheat (Triticum aestivum L.). - Environ. Toxic. 20: 195-201, 2005.

Takahashi, R., Ishimaru, Y., Shimo, H., Ogo, Y., Senoura, T., Nishizawa, N.K., Nakanishi, H.: The OsHMA2 transporter is involved in root-to-shoot translocation of $\mathrm{Zn}$ and $\mathrm{Cd}$ in rice. Plant Cell Environ. 35: 1948-1957, 2012.

Wang, J., Yuan, J., Yang, Z., Huang, B., Zhou, Y., Xin, J., Gong, Y., Yu, H.: Variation in cadmium accumulation among 30 cultivars and cadmium subcellular distribution in 2 selected cultivars of water spinach (Ipomoea aquatica Forsk.). - J. Agr. Food Chem. 57: 8942-8949, 2009.

Wang, M., Xu, Q., Yu, J., Yuan, M.: The putative Arabidopsis zinc transporter ZTP29 is involved in the response to salt stress. - Plant mol. Biol. 73: 467-479, 2010.

Wang, P., Deng, X., Huang, Y., Fang, X., Zhang, J., Wan, H., Yang, C.: Comparison of subcellular distribution and chemical forms of cadmium among four soybean cultivars at young seedlings. - Environ. Sci. Pollut. Res. 22: 19584-19595, 2015.

Wang, X., Cheng, Y., Shuai, W., Zeng, J., Kang, H., Fan, X., Sha, L., Zhang, H., Wang, Y., Zhou, Y.: Nitrate $\mathrm{N}$ influences the accumulations and subcellular distributions of $\mathrm{Cd}$ and $\mathrm{Zn}$ to mediate the $\mathrm{Cd} / \mathrm{Zn}$ interactions in dwarf Polish wheat (Triticum polonicum L.) seedling. - Soil Sci. Plant Nutr. 65: 137-147, 2019.

Wang, X., Shi, M., Hao, P., Zheng, W., Cao, F.: Alleviation of cadmium toxicity by potassium supplementation involves various physiological and biochemical features in Nicotiana tabacum L. - Acta Physiol. Plant. 39: 132, 2017a.

Wang, X., Zhi, J., Liu, X., Zhang, H., Liu, H., Xu, J.: Transgenic tobacco plants expressing a P1B-ATPase gene from Populus tomentosa Carr. (PtoHMA5) demonstrate improved cadmium transport. - Int. J. Biol. Macromol. 113: 655-661, 2018.

Wang, Y., Wang, X., Wang, C., Peng, F., Wang, R., Xiao, X., Zeng, J., Kang, H., Fan, X., Sha, L., Zhang, H., Zhou, Y.: Transcriptomic profiles reveal the interactions of $\mathrm{Cd} / \mathrm{Zn}$ in dwarf Polish wheat (Triticum polonicum L.) roots. - Front. Physiol. 8: 168, 2017b

Wang, Y., Wang, X., Wang, C., Wang, R., Peng, F., Xiao, X., Zeng, J., Fan, X., Kang, H., Sha, L., Zhang, H., Zhou, Y.: Proteomic profiling of the interactions of $\mathrm{Cd} / \mathrm{Zn}$ in the roots of dwarf polish wheat (Triticum polonicum L.). - Front. Plant Sci. 7: 01378, 2016.

Wiwart, M., Suchowilska, E., Kandler, W., Sulyok, M., Groenwald, P., Krska, R.: Can polish wheat (Triticum polonicum L.) be an interesting gene source for breeding wheat cultivars with increased resistance to Fusarium head blight? - Genet. Resour. Crop Evol. 60: 2359-2373, 2013.

Wu, F., Dong, J., Qian, Q., Zhang, G.: Subcellular distribution and chemical form of $\mathrm{Cd}$ and $\mathrm{Cd}-\mathrm{Zn}$ interaction in different barley genotypes. - Chemosphere 60: 1437-1446, 2005.

Wu, H., Cheng, C., Du, J., Liu, H., Cui, Y., Zhang, Y., He, Y., Chu, C., Feng, Z., Li, J., Ling, H.: Co-overexpressing FIT with AtbHLH38 and AtbHLE39 in Arabidopsis-enhanced cadmium tolerance via increased cadmium sequestration in roots and improved iron homeostasis of shoots. - Plant Physiol. 158: 790-800, 2012.

Xin, J., Huang, B., Dai, H., Liu, A., Zhou, W., Liao, K.: Characterization of cadmium uptake, translocation, and distribution in young seedling of two hot pepper cultivars that differ in fruit cadmium concentration. - Environ. Sci. Pollut. Res. 21: 7449-7456, 2014.

Xu, L., Wang, Y., Liu, W., Wang, J., Zhu, X., Zhang, K., Yu, R., Wang, R., Xie, Y., Zhang, W., Gong, Y., Liu, L.: De novo sequencing of root transcriptome reveals complex cadmiumresponsive regulatory networks in radish (Raphanus sativus L.). - Plant Sci. 236: 313-323, 2015.

Yang, C., Juang, K.W.: Alleviation effects of calcium and potassium on cadmium rhizotoxicity and absorption by soybean and wheat roots. - J. Plant Nutr. Soil Sci. 178: 748754, 2015

Zhang, Y., Xu, Y., Yi, H., Gong, J.: Vacuolar membrane transporters OsVIT1 and OsVIT2 modulate iron translocation between flag leaves and seeds in rice. - Plant J. 72: 400-410, 2012. 
Zhao, Z., Xi, M., Jiang, G., Liu, X., Bai, Z., Huang, Y.: Effects of IDSA, EDDS and EDTA on heavy metals accumulation in hydroponically grown maize (Zea mays, L.). - J. Hazard. Mater. 181: 455-459, 2010.
Zhao, Z.Q., Zhu, T.G., Li, H.Y., Smith, S.E., Smith, F.A.: Effects of forms and rates of potassium fertilizers on cadmium uptake by two cultivars of spring wheat (Triticum aestivum L.). Environ. Int. 29: 973-978, 2003. 